סימני-השינויים-הפונטיים -בתרגום-הלשוני-בספר-איוב

\title{
علاهات التغيرات الصوتية في ترجمة سفر ايوب
}

\author{
مبم اممد سعبيد عبـيد \\ كلية اللغات - جامعة بغدادي
}

\section{הקדמה}

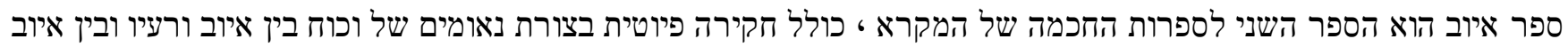

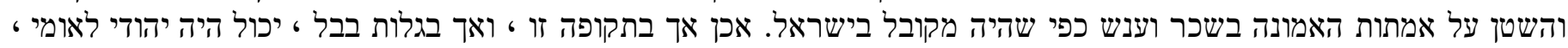

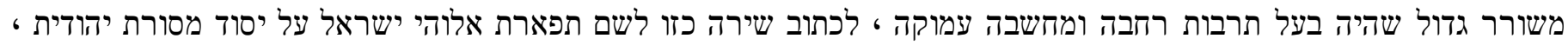

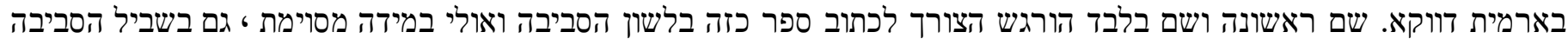

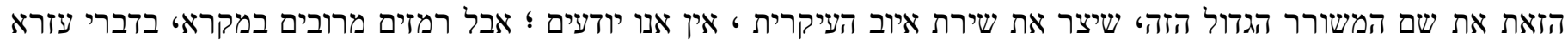

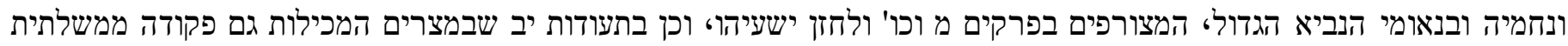

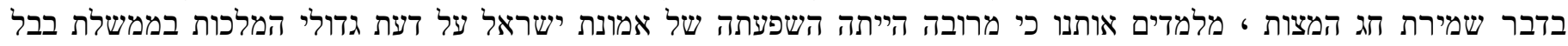

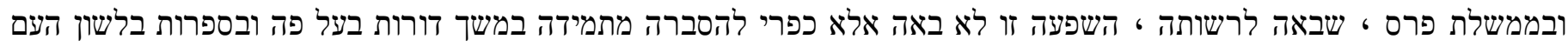

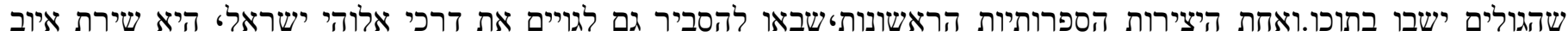

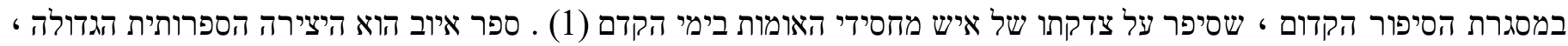

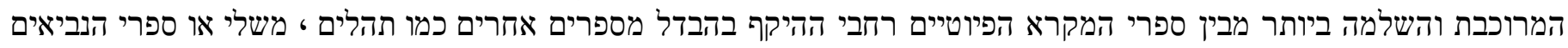
הגדולים מבחינת הבנין הלשוני .

\section{ספר איוב ، תרגום ארפי}

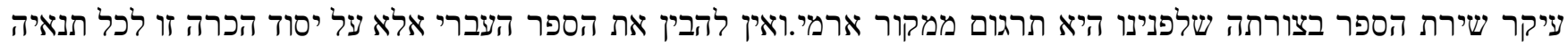

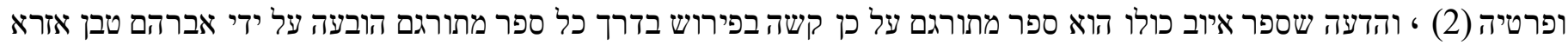

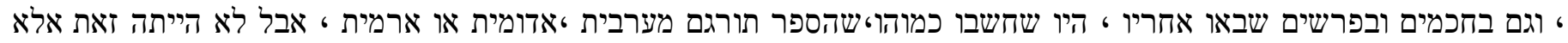

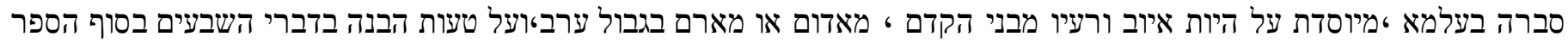

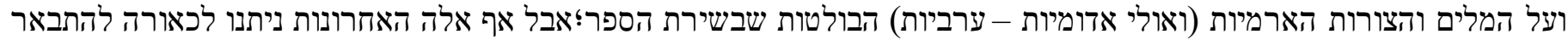

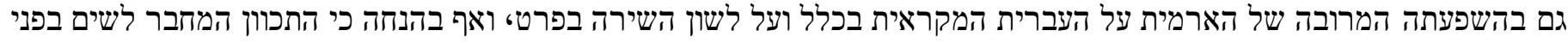

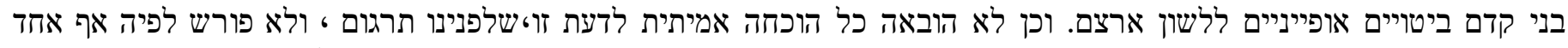

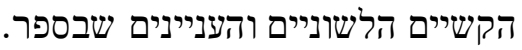

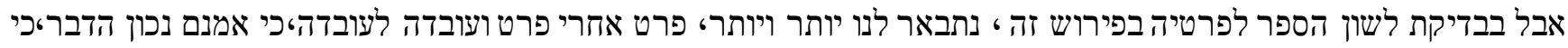

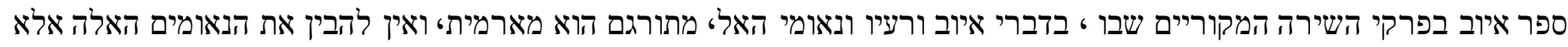
בשימנו עובדה זו לנגד עינינו.

מכלל הנאמר כאן על פרשת השירה של ספר איוב ‘אשר כל כך מרובות בה העדויות למקורה בלשון אחרתי חורג (מלבד פרשת

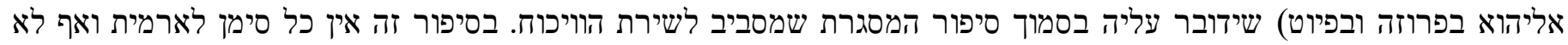

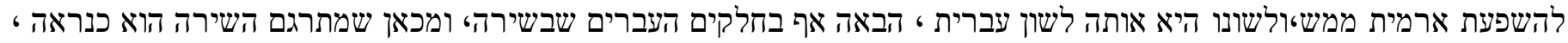

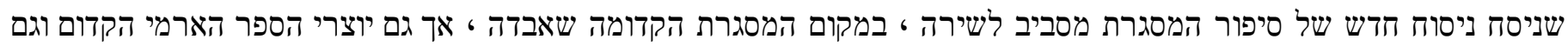

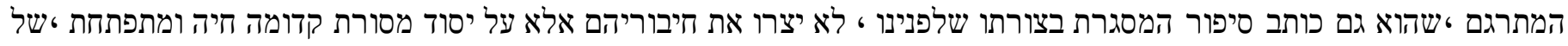

היסטוריה ואגדה יחד כמבואר בהמשך בפסר קדומה מיה מיוחד (3) .

\section{שיטיטת התרגום לשירה בספר איוב}

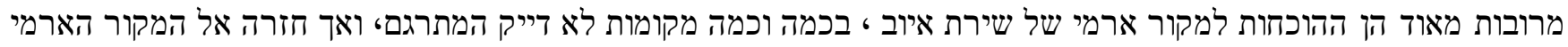

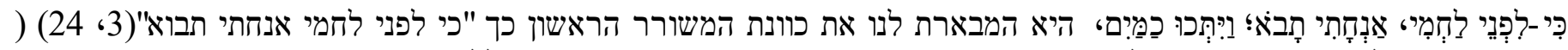

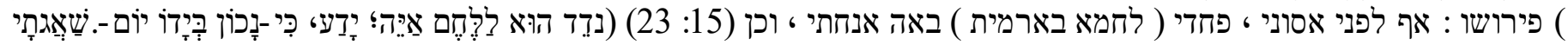

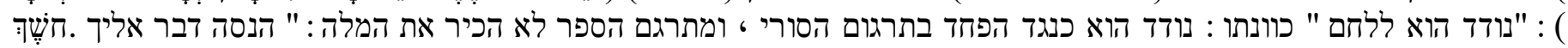

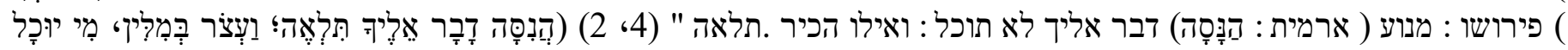

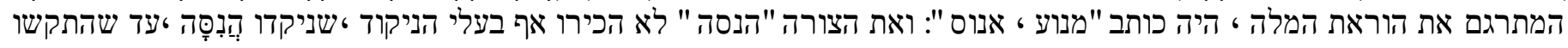

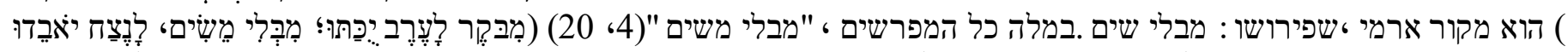

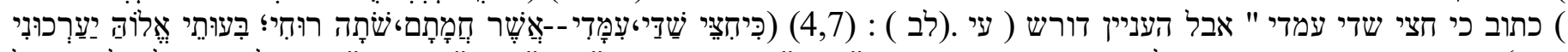

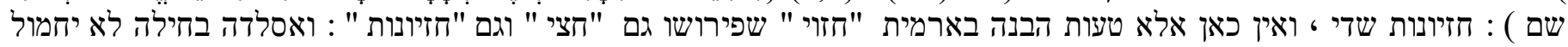

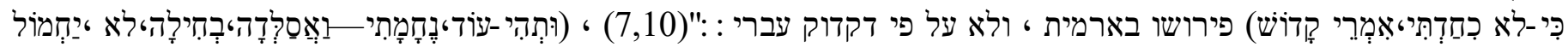




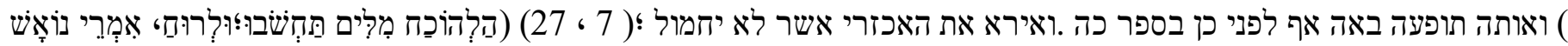

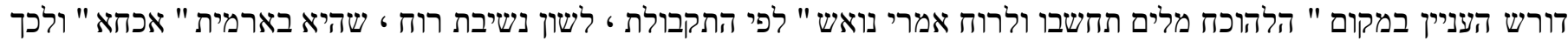

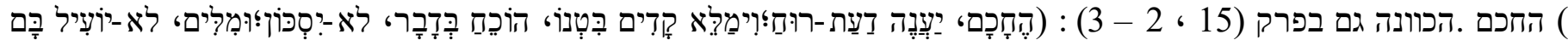

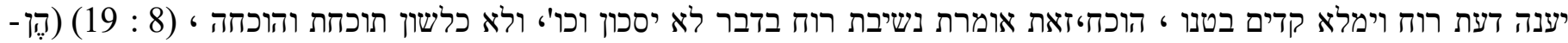

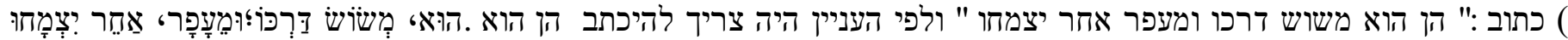

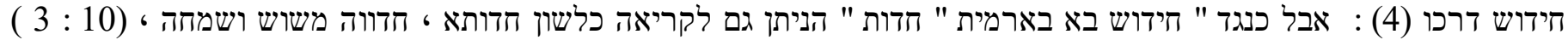

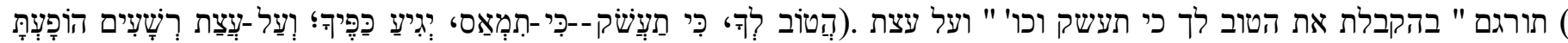

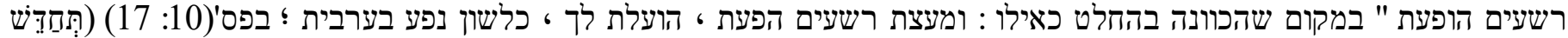

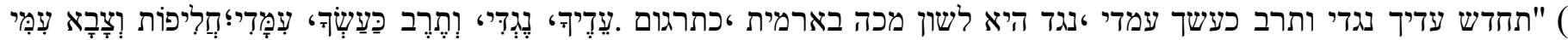

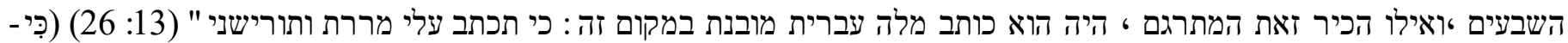

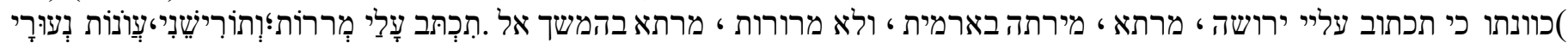

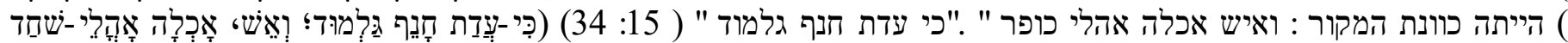

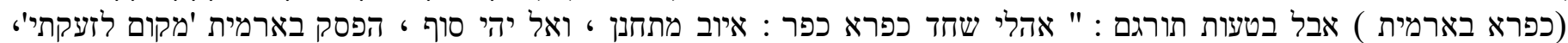

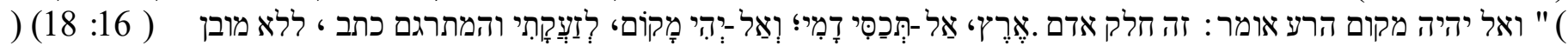

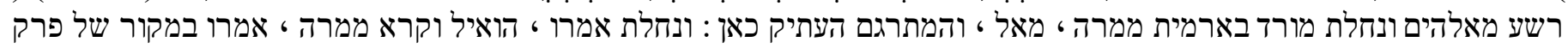

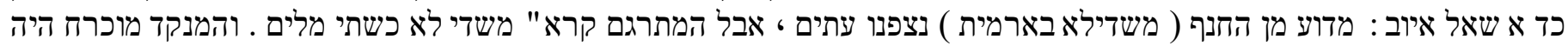

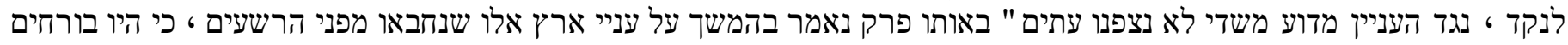

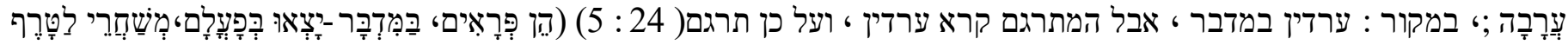

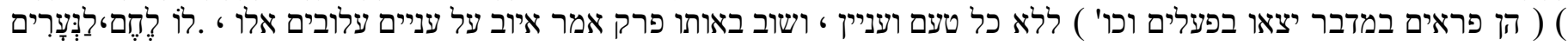

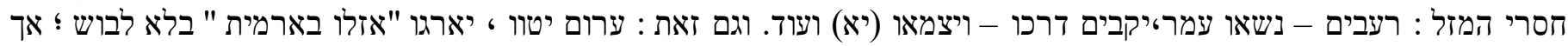

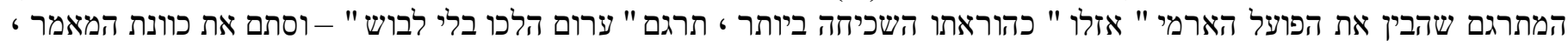

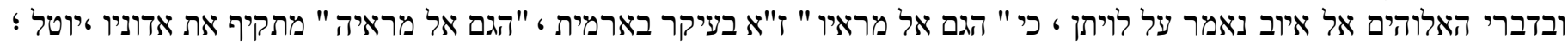

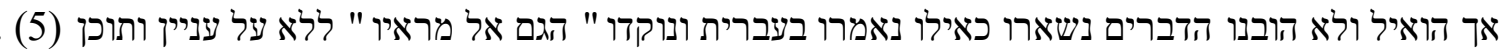

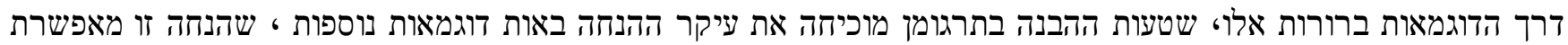

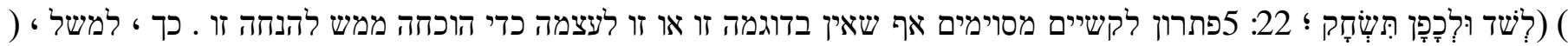

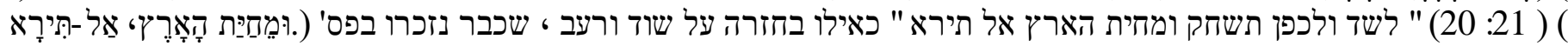

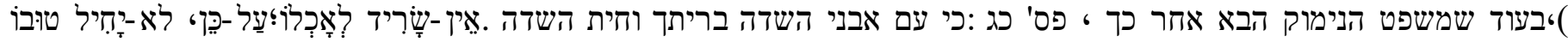

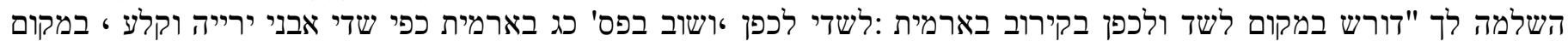
התרגום: אבני השדה • ומכאן גם כפילות כלפית המלה השדה בחרוז זה ועוד.

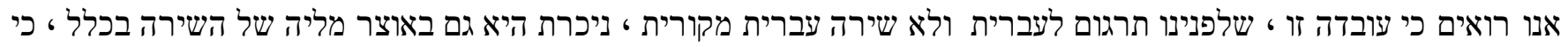

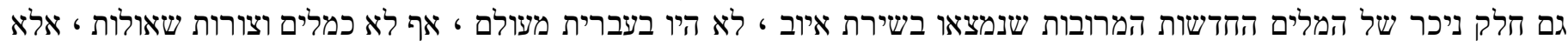

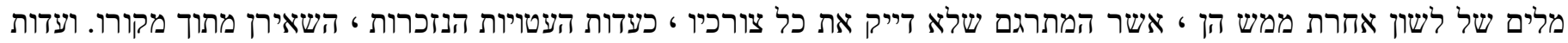

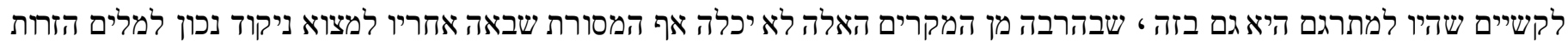

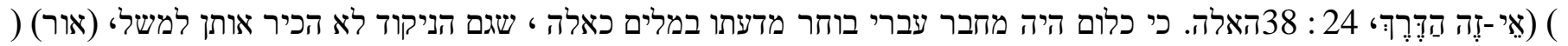

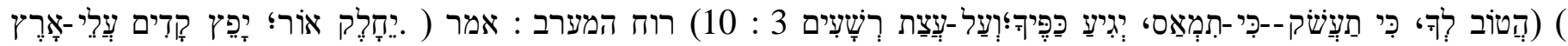

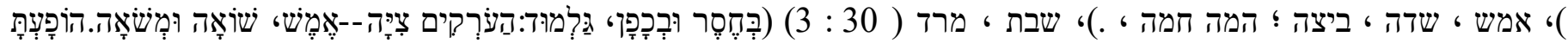

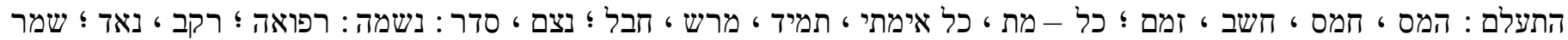

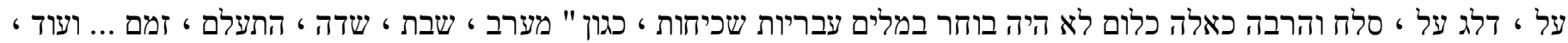

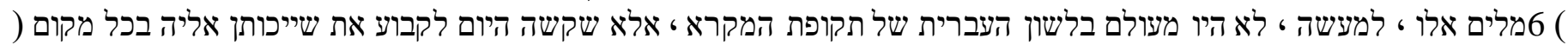

\section{תרגום לשון הספר}

על יסוד הכרה זו בלבד מתבארות כמה וכמה תופעות בלשון הספריידועות ובולטות הן לא רק המלים הפים הארמיות אליות אלא גם הצורות

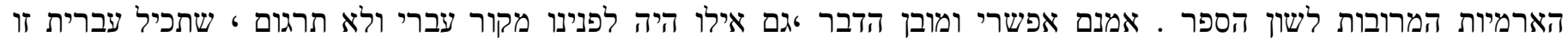

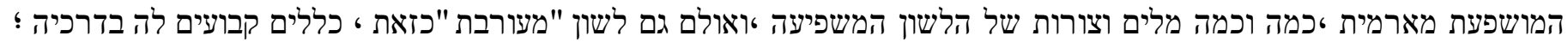

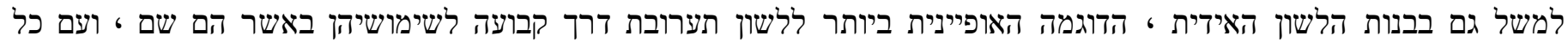

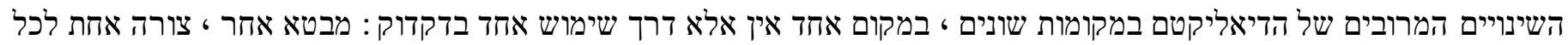

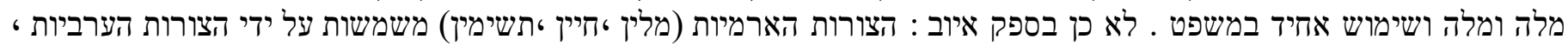

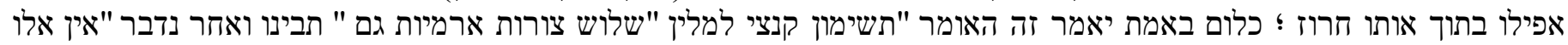

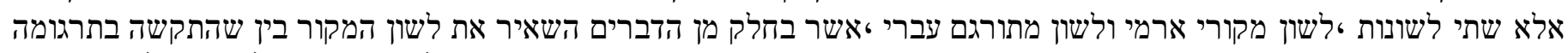

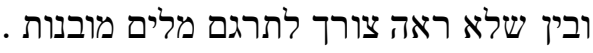




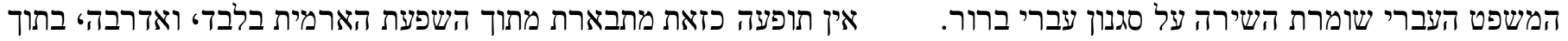
(

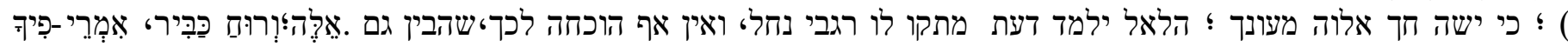

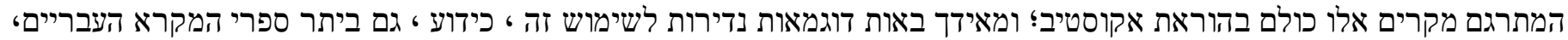

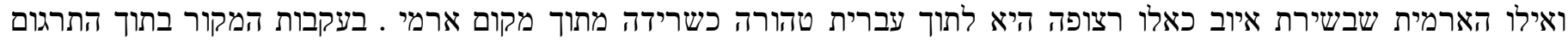

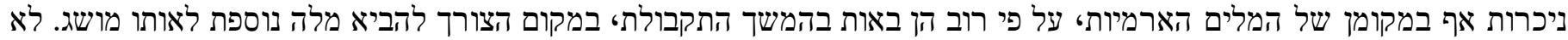

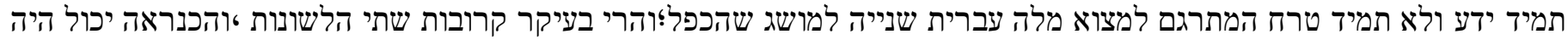

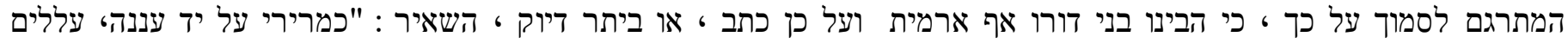

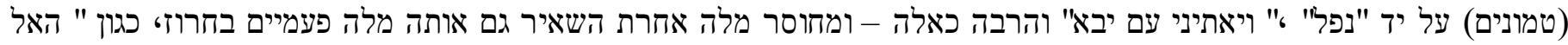

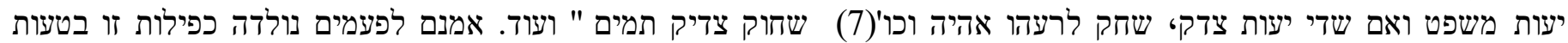

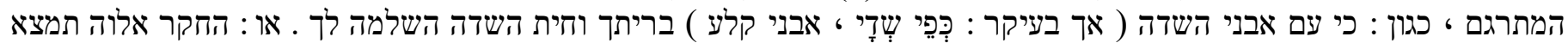

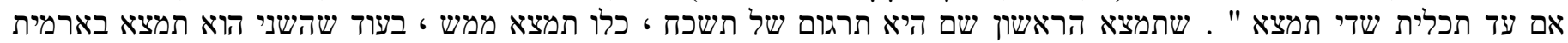

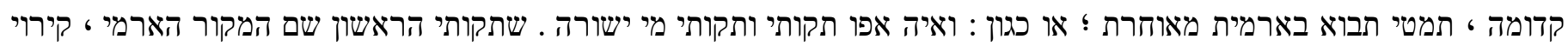

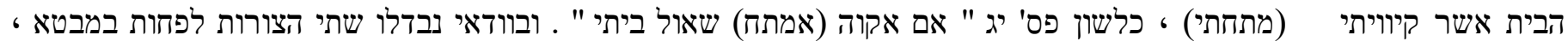
בלשון המקור.

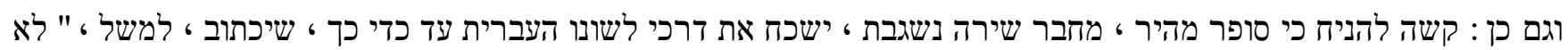

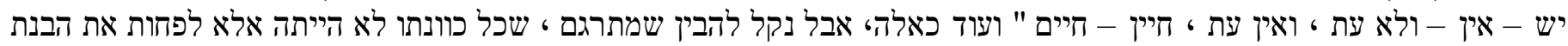

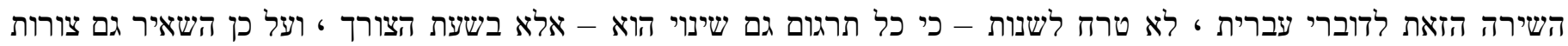

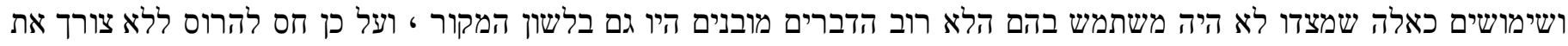
מבנה המקור.

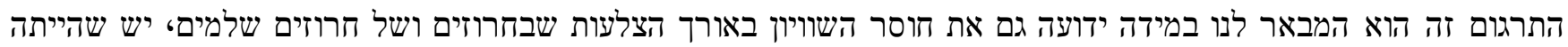

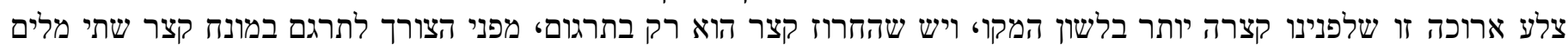

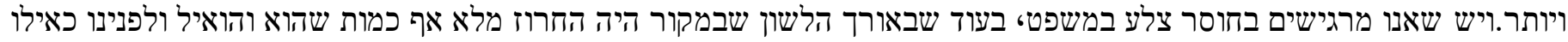

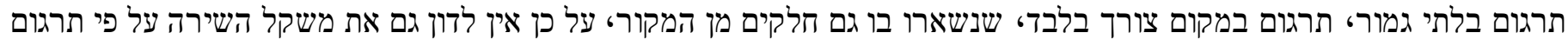

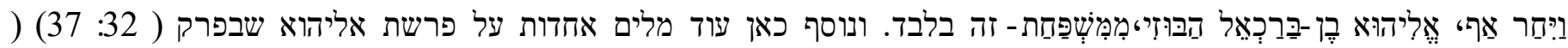

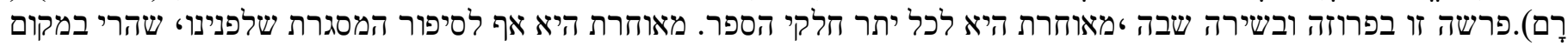

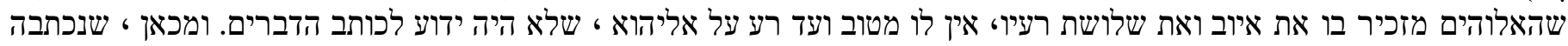

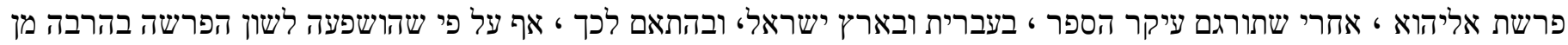

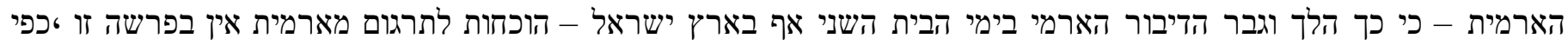

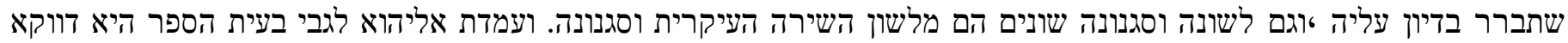

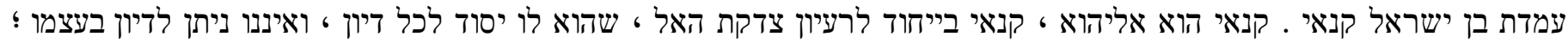

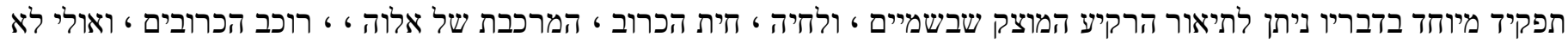

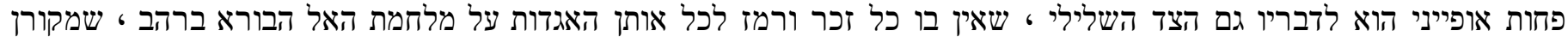

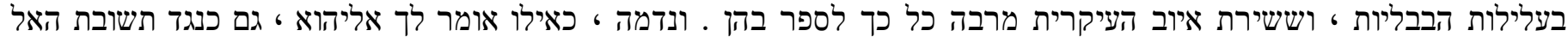

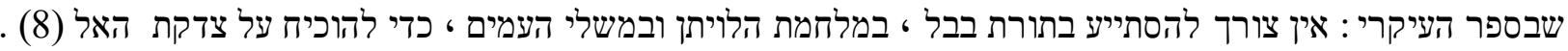

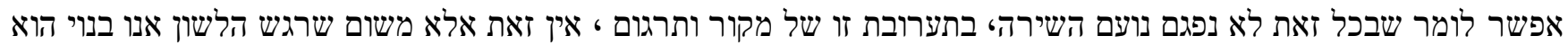

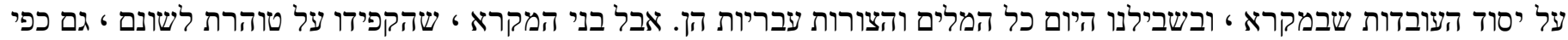

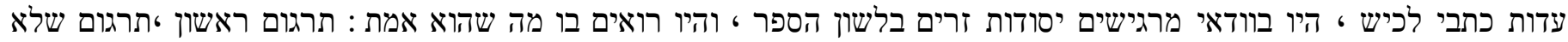

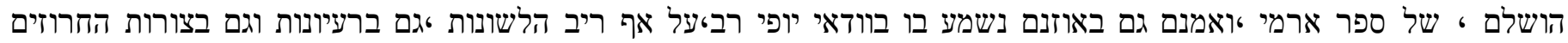

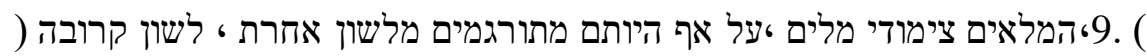

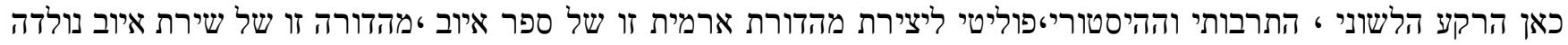

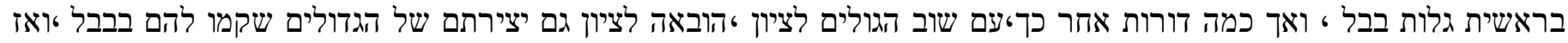

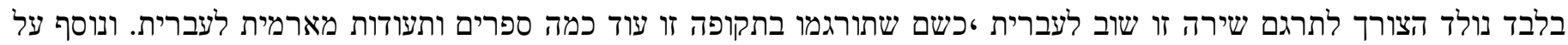

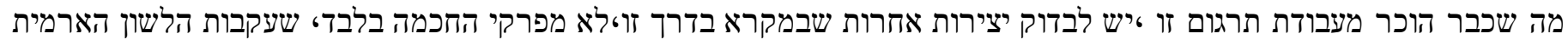

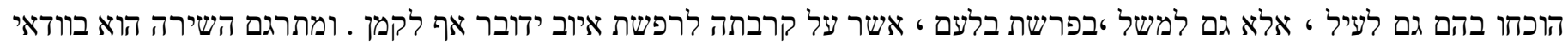

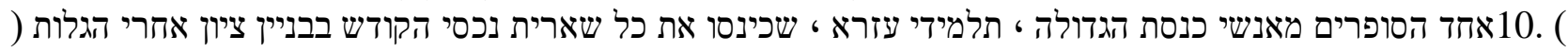

\section{שיפוי האותיות בארמית ובעברית}

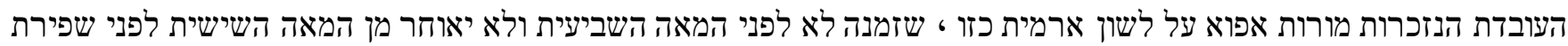

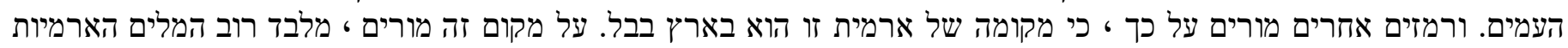




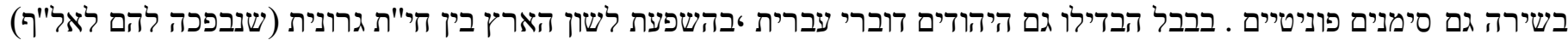

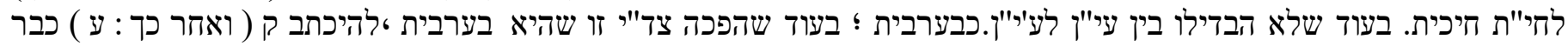

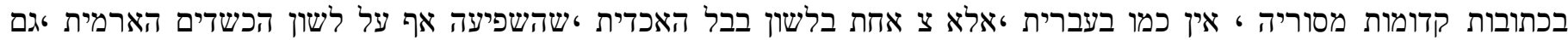

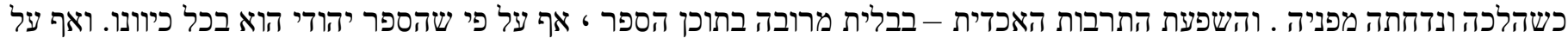

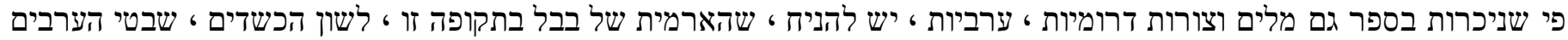

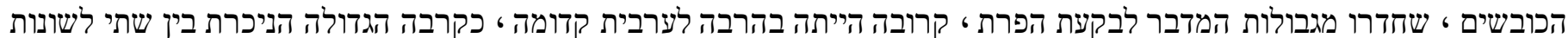

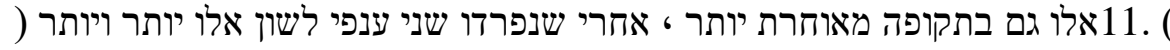

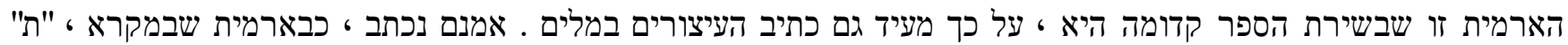

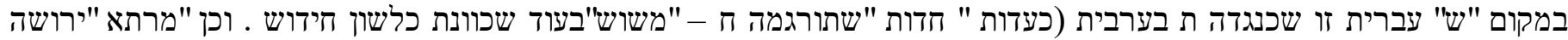

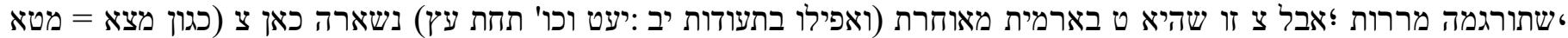

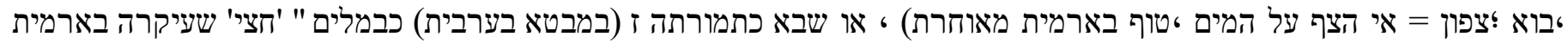

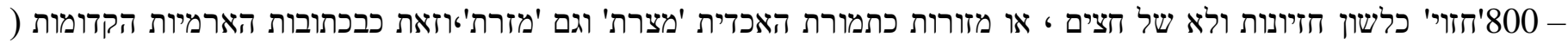

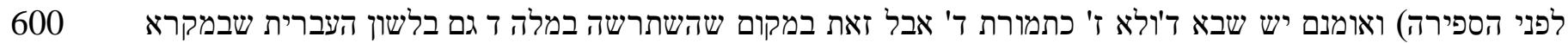
) 12.(

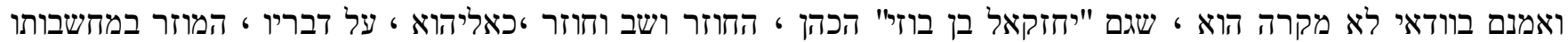

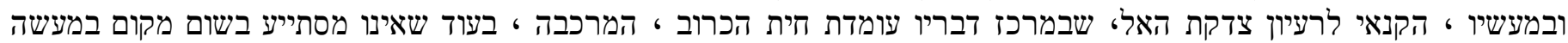
גבורות האל בלויתן ، שהוא ، מכל הנביאים מזכרים בזכיר את איוב כנושא אקטואלי בזמנום במשום

'והיו שלשת האנשים האלה בתוכה נח דנא ואיוב המה בצדקתם ינצלו נפשם ' . כלום אין השם " אליהוא ביה ביה ברכאל הבוזי בא לרמוז

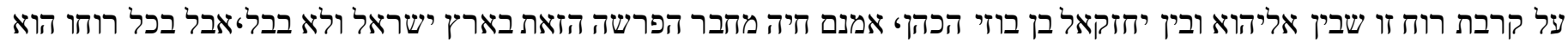

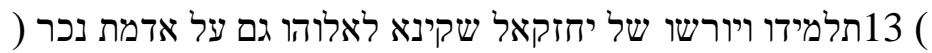

\section{סיכופ}

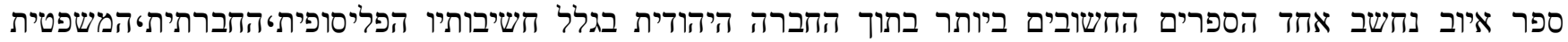

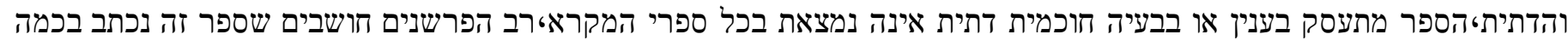

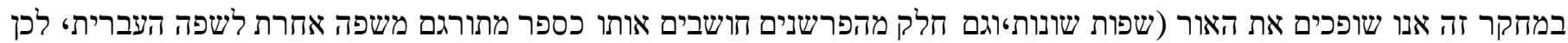

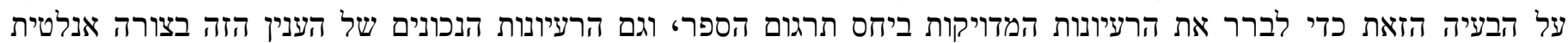

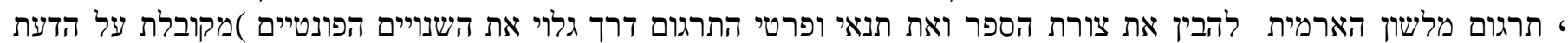
המלוות את תרגומו הלשוני.

\section{الخلاصــــة}

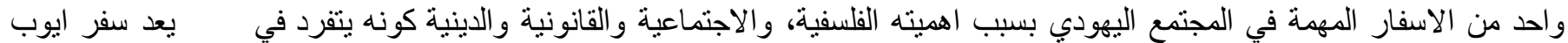

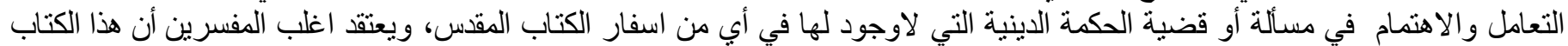

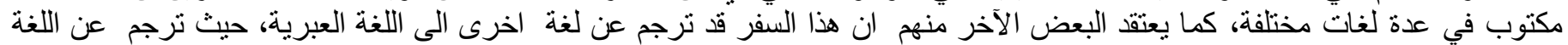

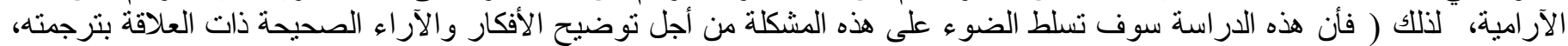

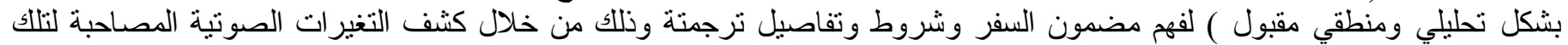
الترجمة

\section{$\underline{\text { Abstract }}$}

The Book of Ayoub is one of the most important Books for the Jewish community due to its philosophical, social, legal and religious significance ; moreover, the mentioned Book is the only Book which deals and touches upon the religious wisdom which is not found in any other Books of the Bible. Most interpreters believe that this book is written in many different languages. Some other interpreters believe that this book is translated the Aramaic language into Hebrew. The present study sheds lights on the different aspects related to this issue . A logical and analytical approach is necessary to understand the content of the Book and the details of its translation through detecting the acoustic variations associated with translation .

הערות שולים

12 עמ',1989 , ברלין, המקרא בקשוטו , ארנולד ,- אירלקי 1.

37 עמ', 1988, ירושלים , ספר היובל עיוני מקרא , עיונים נבחרים בפרוש חדש למקרא , משה ,-גרסאל 2 
13 עמ', 2010 , ישראל , עיונים בשפה בחברה , דליה , נורי ,- גבראל 3

57.

69 עמ', 1994 , ירושלים ,ניגון טעמי המקרא ,צאניך מאיר, - ווייל 5.

116 עמ', 1989 עמ', 1999.

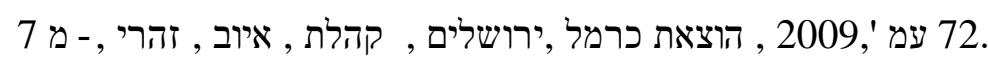

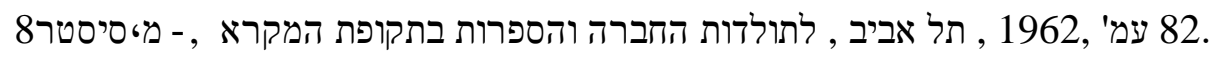

. 93 עמ', 1982 , ירושלים , ראובן מס , ספר איוב , נ ,טור , - - סיני 9

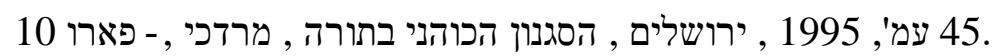

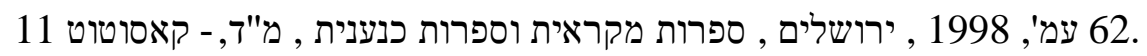

49 עמ", שם ,- גבראל 12.

128.

המקורות

1989.

2010.

1988.

1990.

1994.

1989.

2009.

1962.

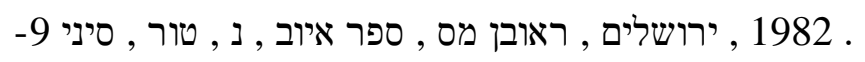

1995.

1998. 